\title{
Interview with Zaleha Kamaruddin
}

\author{
Ahmad Yousif
}

\begin{abstract}
In Southeast Asia and elsewhere in the Muslim world, academic institutions - particularly in the humanities and social sciences often ignore the potential leadership role of women. This is especially evident in Islamic studies, where women play a minor role in research, teaching, and course management. Generally speaking unlike in the Middle East, many public and private Southeast Asian schools of higher learning, as well as "Islamic" schools, feature female Muslim scholars in their administrational structures. Indonesia boasts several woman serving as leaders in Islamic educational organizations, and Masnon Ibrahim is the current rector of Brunei's Seri Begawan Religious Teachers University College. On the international level, Zaleha Kamaruddin, the recently appointed rector of the International Islamic University Malaysia (IIUM), remains the world's first and only female rector of an Islamic institution of higher learning.
\end{abstract}

This short article seeks to address her feelings, style, and role, as well the challenges in managing an international Islamic institution. It is based on her written answers to written questions, a recent unstructured interview, and personal contact gained while working together as administrators at IIUM during the 1990s.

Officially known at IIUM as Prof. Dato Sri Dr. Zaleha Kamaruddin, the rector was born and raised in Malaysia. After earning a bachelor of law (with honours) degree in 1985 from the University of Malaya, the following year she joined the Malaysian Bar Council. Among the first student intakes for IIUM's master's program in comparative law, she received her degree in 1988. Soon thereafter Kak Leha, as she is called by her Malay friends at work, acquired an advanced diploma in Shari' ah law and practice from IIUM. In 1990, she entered a doctoral program in comparative family law at the University of London (England) and graduated four years later. Upon her return, she joined IIUM in 1992 as an assistant professor, became an associate professor in 2000, and a full professor at the Ahmad Ibrahim Faculty of Law in 2006. 
Her quarter century of administrative service includes appointments as deputy dean of student affairs (1994), deputy dean of the Research Management Centre (2000), dean of the Centre for Postgraduate Studies (2003), and dean of the Ahmad Ibrahim Faculty of Law (2006). She was then seconded for two years (2009-11) as deputy director-general of the Institute for Islamic Understanding Malaysia. As of 2012, she is serving as IIUM's rector.

Kamaruddin's research has focused on Malaysian family issues, such as the participation of Muslim women in society. For example, in 2005 she spent her sabbatical leave leading a major consultancy project on "Assessing Delays in the Disposition of Matrimonial Cases in the Malaysian Shari'ah Courts." This later became the foundation for the government-funded Family Support Authority. During her tenure as dean of the Faculty of Law, she proposed to the attorney-general's chambers several important projects, among them offering to certify their officers via an LL.M. program in the administration of Islamic law. This faculty has also enlisted the Malaysian Bar Council's collaboration to offer an academic program in Islamic banking for civil lawyers. The Law Centre, which has been the faculty's business and intellectual focal point since 1998, has been managing the above programs. ${ }^{1}$

A prolific writer, Kamaruddin has published seventeen books and presented more than 200 papers at local and international conferences, among them the recent al-Sanhuri Annual Lecture at the Harvard School of Law on the transformation of the Islamic legal system. She also contributes to the national press (e.g., Mingguan Malaysia, Berita Harian, and The Star) and has her own radio program on Radio IKIM.FM: "Mahligai Kasih" ("My Castle").

An internationally recognized authority on comparative family law and a respected figure in the Asian legal community, over the last two decades she has been a member of the International Society of Family Law and the International Society for the Prevention of Child Abuse and Neglect. In 2007 she was invited to join the Law Association for Asia and the Pacific. From 2005-09 she was appointed a member of the Board of Governors for the Asian Law Institute at the National University of Singapore.

Kamruddin received the Excellent Researcher Award (on the faculty level), in both 2004 and 2005, and in 2008 Dutch publisher Kluwer Law International bestowed its Excellent Research Award upon her team. Moreover, the United Nations Human Settlements Program (UN-Habitat) appointed her to conduct training sessions for their program in Malaysia. And yet she still finds time to serve as chief editor of IKIM's Tafhim: Journal of Islam and the Contemporary World while maintaining her editorial membership of The Journal of Governance and Law, the Journal of Shari 'ah and Law, The International Journal of Muslim Unity, and other scholarly journals. 
In 2009, she became chair of Legal and Constitutional Affairs and was invited to deliver a paper to the United Kingdom's House of Lords. She has been a member of the Malaysian state of Selangor's Council of Religious Affairs since 2003, while chairing its Family Development Committee, as well as a member of the Fatwa Committee of Selangor and the Fatwa Committee of the state of Pahang. In 2007, the sultans of Selangor and Pahang bestowed royal awards upon her.

Among other professional positions, Kamaruddin has been a member of the Technical Committee on Shari'ah and Civil Law (under the prime minister's Department of Religious Affairs), as well as a member of the National Religious Council. Due to her expertise in family law, the Minister of Women, Family, and Community Development appointed her as a member of the National Women's Advisory Council. In 2010, she was selected as chair of the National Panel on Current Issues on Women and Islam.

The following exchange is based on a few written questions with direct responses from Dr. Kamaruddin.

Question\#1: How do you feel about your appointment as a female Muslim rector of the International Islamic University Malaysia (IIUM)?

Answer: First of all, I feel thankful and duty-bound to Allah for this opportunity to be at the helm of a leading Islamic university, which is a big responsibility. I was the dean of the Faculty of Law at this university a few years ago, and there are many women leaders and CEOs in Malaysia and the Islamic world, so the hype about gender is a bit exaggerated. Accordingly, the point of focus for me after this appointment is not gender, but rather the leadership responsibility that I have to shoulder. The point of focus is achieving the mission of the university in nurturing quality holistic education that is imbued with Islamic moral-spiritual values, as exemplified in our international community of dedicated intellectuals, professionals, and students (male and female) who are motivated by the Islamic worldview and code of ethics as an integral part of their life and culture.

Question \#2: A common image of Muslim women in the global media today is that they are oppressed, depressed, stressed. What do you think about that? Answer: The active contribution of women and their involvement in all facets of economic and political life is not new to Islam. This matter, of course, has come to the fore in the past century, due to what some say is the colonial impact. Still, the debate about such participation is natural and vital in any society, as this issue affects most of its members. It remains a fact that female Muslims nowadays have professionally entered all fields of business. There 
are many social ills and problems across the Muslim world, and I can tell you this as one who specializes in the implementation of family law. Having said that, the media should be fair in their portrayal of Muslim societies. Yet, the word "media" you use is very general, and of course different mass media outlets may have different agendas.

Question \#3: The prospect for female leadership in the Muslim world is still not very bright compared to that of the West. How does the situation in Malaysia compare to that in the West and other parts of the Muslim world? Answer: Malaysia actively participated in the United Nations Convention on the Elimination of All Forms of Discrimination against Women and is committed first and foremost to the course of moderate Islam that guarantees women all their rights. The strongest feature of Malaysian society is tolerance; I can tell you that. The government and the civil society are working hand in hand to achieve gender equity and family development as the basis for the formation of a developed nation by 2020. Women in Malaysia are [government] ministers, professors, CEOs of banks and state corporations, and they work in all positions of the private and public sector. In my honest opinion, the prospects for female leadership in Malaysia are very high.

Question \#4: The International Islamic University Malaysia is seeking to be recognized as a research university by international standards. What steps and plan do you have in mind to achieve such a great task?

Answer: We have to always bear in mind and remind one another that one way to excel and help one another is through research and development (R\&D). Today, we realize that teaching alone is insufficient to achieve our aim for educational and comprehensive excellence. As such, IIUM fully recognizes that R\&D are not merely complementary to teaching, but they are also vital to its gradual progress towards comprehensive excellence.

In 2008, the Ministry of Higher Education (MoHE) launched the Malaysian Higher Education Strategic Plan until 2020, which outlines six main strategic thrusts towards achieving excellence in higher education. One of the thrusts is enhancing research and innovation; another is intensifying internationalization. IIUM has already set such goals in its Strategic Plan 2007-2015, stating the need to strengthen its R\&D activities, to obtain research university status from the MoHE, and to better serve the community and the Ummah through internationalization.

IIUM's intention to achieve Research University status is in full swing with concerted efforts to produce quality research for submission to the MoHE. Currently, a team of academic and administrative staff, as well as stu- 
dents, is working very hard to collate research data from 2009 to 2011 to fulfill the MoHE requirements. In terms of research and innovation, our university might achieve the threshold score in less than a year. I always stress that we have to pursue this Research University status with soul, reflecting our mission and vision of being a role model for the Islamization of knowledge.

Question \#5: How do you perceive the future of IIUM?

Answer: Currently, we are preparing our strategic plan to take concrete measures in competing with other world-class universities. Apart from pursuing the path of attaining the MoHE designation of Research University, we are also determined to achieve the status of a leading international academic research institution imbued with Islamic values. Our strategic goals include internationalizing our vision and mission and attracting the best brains from across the world, especially Muslim talent, which will reflect our status as a leading Islamic centre of education.

Question \#6: Any plan to establish research collaborations between IIUM and academic institutions in the West in general, and North America in particular? Answer: In IIUM, we always seek to collaborate with scientific and academic experts and institutions with long experience in their fields as well as in the field of developing higher education, particularly with those who have extensive networks in its related bodies.

The difficult conditions of the Islamic world today compel us to search for realistic solutions and to find answers to our current problems by sharing our experiences. We are confident that a collective Muslim wisdom must exist under the umbrella of ISESCO or the OIC to face the challenges of our modern world. ${ }^{2}$ However, we must first do our part and take positive steps to find solutions to these problems before we rely on the shared wisdom of our brothers [and sisters] in their respective Muslim countries. The same applies to the West. Collaboration with western universities and institutions in North America is currently underway; we have MoUs and active agreements with various institutions. Of course we seek to expand and benefit more from such academic exchanges. We are always open to ideas and proposals.

\section{Endnotes}

1. For more information, visit http://www.iium.edu.my/hmhlawcentre.

2. Editor's note: ISESCO refers to the Islamic Educational, Scientific, and Cultural Organization, and OIC refers to the Organization of Islamic Cooperation. 